\title{
Relationship between Project Consultants' Performance and Project Success in the Rwandan Construction Industry
}

\author{
Elysé Masengesho ${ }^{1}$, Ji Wei ${ }^{1}$, Rosette Niyirora ${ }^{1}$, Nadine Umubyeyi ${ }^{2}$ \\ ${ }^{1}$ School of Civil Engineering, Lanzhou Jiaotong University, Lanzhou, China \\ ${ }^{2}$ Faculty of Engineering, China University of Geosciences, Wuhan, China \\ Email: ‘jiwei1668@163.com, elymaombi@gmail.com
}

How to cite this paper: Masengesho, E., Wei, J., Niyirora, R. and Umubyeyi, N. (2021) Relationship between Project Consultants' Performance and Project Success in the Rwandan Construction Industry. World Journal of Engineering and Technology, 9, 138-154.

https://doi.org/10.4236/wjet.2021.91011

Received: January 6, 2021

Accepted: February 7, 2021

Published: February 10, 2021

Copyright $\odot 2021$ by author(s) and Scientific Research Publishing Inc. This work is licensed under the Creative Commons Attribution International License (CC BY 4.0).

http://creativecommons.org/licenses/by/4.0/

(c) (i) Open Access

\begin{abstract}
As discovered, today's Rwandan construction industry is developing day by day, which plays a very important role in the country's economic growth. In the construction industry, project consultants play a very significant role in providing services for such projects. The project consultants provide services from the beginning of the project to the completion of the project. Using project consultants is very useful for construction projects because it can ameliorate project efficiency and effectiveness. The main purpose of this paper is to investigate the relationship between project consultants' performance and project success in the Rwandan construction industry. The data used in this study were obtained from primary and secondary sources. The secondary data was attained through an elaborated literature review of various books, articles, and papers related to this research to outlining and describing the chief ideas of this research title. The primary data was compiled through a questionnaire survey that was directed to 110 selected professionals in the construction projects in Rwanda to collect data from the site for statistical analysis of the research to test the hypothesis. However, a total of 90 usable responses were received within the scheduled period representing the response rate of $81.82 \%$, which is likely to be representative and acceptable. Data collected from the questionnaire surveys were analyzed using the Statistical Package for Social Scientists (SPSS), excel spreadsheets, and Relative Importance Index (RII), which provide more merit presentations. The survey results show that even if there are many obstacles in the use of project consultants in the Rwandan construction industry such as lack of knowledge and practice in project consulting, lack of well-trained project consulting professionals, lack of training opportunities in project consulting, lack of knowledge and experience in addition to the senior management opposition, and lack of
\end{abstract}


local project consulting guidelines and information; they are needed in the construction project to make it more successful through reducing and saving the overall project's life cycle cost according to client's wishes, keeping time of construction project, improving quality of the project products in the present and future, removing major variations that affect construction project with its attendant cost overrun, and advising on construction project process. Therefore, it is more important to remark that the good performance of the project consultants in any industry especially in the construction industry will contribute to the successful implementation of the project. From the results of the study, the performance of project consultants is closely related to the success of the construction industry in Rwanda. The project consultants' leading skills and knowledge automatically guide the project to complete with accurate time, budget, and quality to make the project successful. In this paper, we will also consider the project success criteria; the role and responsibility of project consultants; the factors affecting the performance of project consultants; and the reasons that hinder the implementation of project consulting in the Rwandan construction industry.

\section{Keywords}

Construction, Project Consultants, Project Success, Project Management, Rwanda

\section{Introduction}

Rwanda is a country that is often plagued by a shortage of skilled project consultants in many economic sectors, especially in the construction sector. Mostly the project owner believes in what the builders/project contractors promise to do throughout the contract documents, contrary they perform the work differently to the client's wishes because they know that he has no knowledge about the construction field and relate in general. If any construction project does not have a competent and knowledgeable consultant the consequences are significant losses for the project owners, where we can say such as cost overrun, project delay, poor project quality, disputes, and the deaths of workers due to there are important requirements that are overlooked during the construction process. Besides, a good project consultant helps any construction company in times of trouble and so on and enables the company to achieve success. Project consulting is more crucial, especially in construction measured throughout the project budget, project completion, and project quality as needed. Therefore, it is very important to know how the project consulting copes with the problems encountered in the project through good cooperation with all involved parts of the project. If the client looks for expert knowledge or advice on certain engineering issues or any issues involving engineering issues, consultation is required [1]. The project consultants will help the clients to overcome current obstacles or avoid future costly mistakes by providing the right help at the right time and de- 
termine and implement solutions to problems faster, thus saving you time and money while their project is more critical and needs to be completed rapidly and correctly. With the project consultant's expertise and objective insights, you will be more efficient than you or your employees. With the construction of new projects, Rwanda's construction industry is developing very rapidly. Due to the rapid development of the construction industry, it is necessary to improve the performance and work quality of the services provided by consulting companies to meet the goals and objectives of the construction project and customer satisfaction [2]. Project consultant manages projects through several services in all construction project stages, such as planning, cost budgeting, value engineering, risk identification, analysis, response and control, schedule optimization, resource allocation, etc. Therefore, the research in this article paper is to investigate the relationship between project consultants' performance and project success of the Rwandan construction industry as it is more significant in the construction industry to have a better understanding of the project consultants' performance and their resultant impacts on project success.

\section{Literature Review}

\subsection{Construction Project Success}

For any country, the success of a construction project is an important issue for most of its economic development, owners, and users [3]. In the project management literature, many researchers have extensively discussed the issue of project success. Wite's opinion was that if the project meets the construction technical performance specifications and the goals to be executed, and is highly satisfied with the project results, the project will be considered as an overall success [4]. Also, Ashley et al. said that the project is successful when having outcomes more beneficial than expected remarked in terms of cost, plan, quality, safety, and all involved parts satisfaction [5]. Most research on project success focuses on how to measure the success of the project and other specific factors that affect the success of the project [6]. For the architects, the project is successful when it bases on aesthetic performance, and for the contractors, the project is more successful when they get more benefits from the project. If the project is completed on time within the budget and everyone is satisfied, the project will be considered a success [7].

On the other hand, Lam et al. described that because the concept of success is still indefinite among project involved parts, it is difficult to measure whether the performance of the project is a success or a failure [8]. Collins and Baccarini pointed out that project success is not only related to completion time, cost, and quality objectives, but also requires relevant education to the project management community [9]. The concept of development project success is to set standards and criteria to help project participants complete the project with the best outcomes [10]. Therefore, when a project reaches the technical performance indicators and goals, the project is regarded to be an overall success, and the or- 
ganization, project team, and users are highly satisfied with the project results [4]. Successful completion of cost, time, and quality goals was considered as direct project management success; project success involves the ultimate project goal [11].

\subsubsection{Project Success Criteria (PSC)}

Generally speaking, PSC is utilized to measure the success of a project. The criteria are the classic solution to the big problems of how to measure the success of a project [12]. Some researchers proposed that PSC should be particular to each project, so it should be decided by stakeholders at the beginning of each project [13] [14]. According to Baccarini, the project success criteria comprises of the following two parts [15]:

\section{1) Project Management Success}

- This is focused on the project procedure, and has three criteria:

- Meet project time, project cost, and project quality targets.

- The project quality management procedure.

- Meeting the needs of project stakeholders for the project management procedure.

\section{2) Product Success}

- This involves the impact of the final product of the project, and it has three criteria:

- Meet the strategic organizational targets of the project owner.

- Meeting users' needs (objectives).

- Meet the product-related needs of stakeholders.

\subsubsection{Project Success Factors (PSF)}

In general, PSF is applied to promote project success. Rockart defined the concept of PSF, as "a limited number of fields in which outcomes if those outcomes are satisfactory, will assure the successful aggressive performance of the project organization" [16]. Belassi and Tukel described that since the 1950s, most of the activity of project management has been focused on project programming troubles or circumstances based on the premise that the growth of better programming techniques will lead to better management and therefore the success of project completion [17]. However, there are many factors beyond the control of project management that could determine project success or project failure, and these factors are called critical success/failure factors [18]. Pinto and Slevin highlighted the main fourteen PSF, which are usually associated with successful implementation across a wide range of project companies and project types [19]. These main success factors are as follows:

- Projects mission

- Top management support

- Project scheduling progress

- Customer consultation

- Personnel recruitment 
- Technical tasks

- Customer acceptance

- Monitoring and feedback

- Communication structure

- Troubleshooting

- Project leader features

- Power and politics influence

- Environmental effect

- Urgency

\subsubsection{Characteristics of Project Success}

In every kind of economic business especially the construction industry, nothing better than to achieve the success of it, so there are main characteristics of that success from the starting point of the project to the end as put out by Baccarini [15] as follows:

1) The Success of Project Management is Subordinate to the Success of Products

The success criteria of time, cost, and quality of project management are subordinate to the product success goals with higher objectives. Accordingly, projects that fail in project management are regarded as project success because the higher-level goal of product success has been achieved.

2) The Success of Project Management Directly Affects the Success of Products

The success of project management directly affects the accomplishment of a product's success. Well, project management contributes to product success, but it is impossible to avoid product failure. For example, project management can assist identify the infeasible project nature and point that the project should be deserted or changed. In terms of cost and/or time overruns, poor project management can lead to failure of the product such as profitability or market share.

3) The success of a project is affected by time

Every measure of success has its time scale. The success of the product can only be judged after the project product is put into use, which may be many years after the project is completed. For the success of project management, it is a short-term measurement standard to judge whether a project has successfully achieved the time, cost, and quality objectives. In the whole process of the project, judge whether the project is carried out in a high-quality way and whether it successfully meets the needs of the project team.

\subsection{Project Consultants Performance in the Construction Industry}

Many construction projects are finished without any conventional project consulting practices. Most of the time these projects are frequently plagued by delays, poor quality, and cost overruns. The key is not just to finish a project, but to finish it correctly. If the project finishes with poor quality, large cost overruns, 
or continuous delays, likely, you and your company will not get the maximum return on your investment from the time and energy you spend. Therefore, to realize project management, firstly you must understand what a construction project is [20]. The management of all sorts of construction projects needs the professional knowledge and comprehensive knowledge system of the organization. The project consultants are characterized by knowledge, performance, and interpersonal skills [1]. The project consultant has no specific definition. Most definitions describe management consulting in terms of the tools, roles, responsibilities, and services provided by skills to perform tasks assigned by the client or project owner [21]. The role and responsibilities of project consultants in the construction industry are very broad and depending on their skills and current experiences. Therefore, if the client looks for expert knowledge or advice on certain engineering issues or any issues involving engineering issues, consultation is required [1]. The project consulting team will provide the right help at the right time to help the clients overcome current obstacles or avoid high-level errors in the future, and determine and implement problem solutions faster, thereby saving you time and money. Without an excellent performance of the project consulting team, it is difficult to ensure the success of the project. Besides, to make the project successful, the manager needs effectively and efficiently to complete the work of the team members. This, together with the introduction of project consultants' knowledge brings about project success [22].

\subsubsection{Role and Responsibilities of the Project Consultants in the Construction Industry}

With its professional knowledge and ability, the project consultants have been undertaking several responsibilities in the construction project for a long time. Since 1984, Rona pioneering research on strengthening the relationship between clients and consultants, many research energy have been committed to investigating the role and responsibilities of project consultants in construction projects [23]. In addition, the appointment of the project manager will influence the success or failure of the project. Therefore, a successful project consultant should perform several roles and responsibilities at the same time, and play a vital role in all stages of the construction project (the initial stage, design stage, construction stage, pre-construction stage, and post-construction stage) [24]. Table 1 below shows the roles and responsibilities of project consultants in different construction stages [1] [24]-[35].

\subsubsection{Leadership Skills of the Project Consultants in the Construction Industry}

The construction industry needs mainly leadership because the success or failure of construction projects largely depends on who leads and coordinates them [24]. However, $80 \%$ of project failures are caused by poor leadership, including insufficient leadership, lack of teamwork, low efficiency of problem-solving and weak communication skills [36]. In addition, some losses or failures of the construction industry have become the object of constant criticism particularly its 
Table 1. Role and responsibilities of the project consultants in the construction industry.

\begin{tabular}{cl}
\hline Project Stages & \multicolumn{1}{c}{ Role \& Responsibility } \\
\hline Initial & $\begin{array}{l}\text { Feasibility studies and plans; identify stakeholders who may influence project } \\
\text { decisions, activities, and results; recording information about stakeholders } \\
\text { including benefits, participation, influence, and the potential effect on the } \\
\text { success of the project. } \\
\text { Review the green design concept, last drawings, and environmental documents } \\
\text { and specifications; and coordinate the design process so that they can deliver } \\
\text { the project following established stakeholders and/or client requirements. } \\
\text { Arrange bidding documents; contractor qualification; bid evaluation; define the } \\
\text { project; project management; architects and consultants appointment; design } \\
\text { process management; set sustainable development targets; provide project cost } \\
\text { estimates; set schedules for the incorporated project teams. } \\
\text { Monitoring project quality and time; supervising contract changes; information } \\
\text { management; team coordination; appointing contractors; site and plan } \\
\text { management; safety management; coordination with customers, architects and } \\
\text { other consultants; procurement management; considering the environmental } \\
\text { effect of the project; control possibilities of risk for avoiding the increase of } \\
\text { costs; and control the added chain. } \\
\text { Packaging and sealing technical and commercial; last cost report; monitoring } \\
\text { whether all sustainability standards are met; and providing customers and } \\
\text { end-users with construction documents related to operation and maintenance. }\end{array}$ \\
Construction \\
ponstruction
\end{tabular}

fragmentary and bad records on project quality, waste, financial claims, safety, and efficiency [37]. One of the reasons for these failures is poor leadership. According to the Project Management Association (PMI), to ensure the effectiveness of project management, project management professionals need to have skills, comprehensive management expertise, and other capabilities [38]. Strict project management skills help to effectively manage the project process [39].

Research shows that there is a powerful correlation between project consultants' leadership skills and project success. The leadership skills, characters, behavior, and attitude of project consultants are very vital because their daily activities affect the behavior and their team members' success [40]. Therefore, according to the literature, the eight leadership skills of construction project consultants in the construction projects are shown in Table 2 below.

\section{Research Approach}

\subsection{Methods of Data Collection}

During this study, the collected data were derived from the primary source and secondary source. The secondary data was gotten from the review of literature of books, articles, and papers related to the study to describe the main concepts about the relationship between project consultants' performance and project success in the Rwandan construction industry. The primary data was developed by a questionnaire survey method that was directed to the employees in the construction companies to collect data from the site for statistical analysis of the research to test the hypothesis. All necessary questionnaires were distributed randomly 
Table 2. Leadership skills of project consultants in the construction industry.

\begin{tabular}{|c|c|}
\hline Author & Leader skills appropriate for project consultants \\
\hline $\begin{array}{l}\text { Zulkiffli et al. [24] } \\
\text { and Serhan [41] }\end{array}$ & $\begin{array}{l}\text { 1) Communication skill } \\
\text { It involves the ability to exchange information with individuals or groups. } \\
\text { This means that the project consultant needs to successfully communicate } \\
\text { with stakeholders to accomplish their sustainable development goals. } \\
\text { Adapting the different views of the project team and stakeholders on } \\
\text { sustainability to ensure the success of the project. }\end{array}$ \\
\hline $\begin{array}{l}\text { Schmid \& Adams } \\
\text { [42] and Zulch [43] }\end{array}$ & $\begin{array}{l}\text { 2) Motivation skill } \\
\text { Motivation skill is the ability to make a person achieve their targets. } \\
\text { Motivation is a skill that the project consultant can use to ensure that the } \\
\text { project team can achieve the project objectives on time according to the } \\
\text { budget. However, the lack of such motivation often conducts to conflicts, } \\
\text { strikes, insufficient productivity, pressure, and project failure. }\end{array}$ \\
\hline $\begin{array}{l}\text { Pryke \& Smyth [37] } \\
\text { and Zulch [43] }\end{array}$ & $\begin{array}{l}\text { 3) Decision making and problem-solving skill } \\
\text { Including the ability and capability to determine and solve problems. } \\
\text { Decision-making is a procedure of gaining the team's commitment to } \\
\text { sustainability and collective support. However, problem-solving is a } \\
\text { procedure for analyzing sustainability criteria and naming possible solutions. }\end{array}$ \\
\hline Giotis [44] & $\begin{array}{l}\text { 4) Conflict management skill } \\
\text { It is the ability to resolve conflicts positively. Conflict management is also } \\
\text { regarded as one of the crucial soft skills for a project consultant to achieve } \\
\text { project success. }\end{array}$ \\
\hline $\begin{array}{l}\text { Bruce }[45] \text { and } \\
\text { Farooqui [46] }\end{array}$ & $\begin{array}{l}\text { 5) Delegation skill } \\
\text { It includes working with subordinates to determine direction, authority, and } \\
\text { responsibility. Without this skill, the project consultant's ability to manage } \\
\text { the team and deliver outcomes will be limited. This is very significant to } \\
\text { make full use of the project team, and the project consultant provides the } \\
\text { ability and capability to pay attention to the real situation. }\end{array}$ \\
\hline $\begin{array}{l}\text { Farooqui [46] and } \\
\text { Glavinich [47] }\end{array}$ & $\begin{array}{l}\text { 6) Planning and goal setting skill } \\
\text { It includes the planning process and the ability to accomplish the wanted } \\
\text { aims. In the process of planning and scheduling, a project consultant should } \\
\text { regard the effect of green standards on the overall progress of construction } \\
\text { projects. In addition, setting feasibility or viable and sustainable priorities } \\
\text { during a construction project will help to demonstrate a framework or model } \\
\text { for all future conclusions making. }\end{array}$ \\
\hline $\begin{array}{l}\text { Foley \& Macmillan } \\
\qquad[48]\end{array}$ & $\begin{array}{l}\text { 7) Team building skill } \\
\text { A team is defined as a team of person who has skills that are devoted to } \\
\text { common goals and are mutually responsible for their achievements. The } \\
\text { project consultant should also be involved in team-building skills to ensure } \\
\text { the success of the project. }\end{array}$ \\
\hline APM [49] & $\begin{array}{l}\text { 8) Negotiation skill } \\
\text { It includes the ability to find common ground and achieve agreements to } \\
\text { solve problems. Project consultants need to use negotiation skills throughout } \\
\text { the project life cycle. }\end{array}$ \\
\hline
\end{tabular}

either personally or via email amongst the selected professionals and a total of 110 questionnaires were submitted as follows: 16 questionnaires were distributed to clients, 29 to project contractors, 26 to project consultants, 19 to design managers, and 20 to quantity surveyors. A total of 90 usable responses were received 
within the scheduled period, but 20 were not returned. This response rate was finally achieved after several efforts were made in terms of follow-up emails and calls. The response rate of $81.82 \%$, which is likely to be representative and acceptable.

Table 3 below shows how many questionnaires were distributed and collected from the respondents.

\subsection{Methods of Data Analysis}

This involved processing, editing, coding, classification, and tabulation of all data collected so that it can be analyzed. The data set after coding was posted to a worksheet for data cleaning to remove errors. Data collected from the questionnaire surveys were analyzed using the Statistical Package for Social Scientists (SPSS) and excel spreadsheets for influence rates of project consultants in terms of time, cost, and quality, while the Relative Importance Index (RII) used to rank the reasons of the need of project consultants, the factors affecting the performance of project consultants, and the reasons that may hinder the implementation of project consultancy in the Rwandan construction industry. Thus, those all methods provide more merit presentations. The Relative Index Analysis (RIA) for each variable is calculated by using the formula as follows: "Very important" equals 5 points, "Important" equals 4 points, "Medium important" equals 3 points, "Low important" equals 2 points, and "Not important" equals 0 points.

Relative Importance Index (RII) was used for each category and calculated as follows:

$$
\mathrm{RII}(\%)=\frac{\mathrm{RIA}}{N}
$$

where: RIA $=100 X_{1}+75 X_{2}+50 X_{3}+25 X_{4}+0 X_{5}$, and $N=X_{1}+X_{2}+X_{3}+X_{4}+X_{5}$

RIA: Relative Index Analysis.

RII: Relative Importance Index.

$X_{1}$ : Number of respondents answering very important.

$X_{2}$ : Number of respondents answering important.

Table 3. Organization response rate in percentage.

\begin{tabular}{cccc}
\hline Types of Organization & Number of Questionnaires & Percentage Returned (\%) \\
\hline & Sent & Returned & \\
\hline Clients & 16 & 12 & 75.00 \\
Project contractors & 29 & 23 & 79.31 \\
Project consultants & 26 & 21 & 80.77 \\
Design managers & 19 & 16 & 84.21 \\
Quantity surveyors & 20 & 18 & 90.00 \\
Total & 110 & 90 & $\mathbf{8 1 . 8 2}$ \\
\hline
\end{tabular}


$X_{3}$ : Number of respondents answering medium important.

$X_{4}$ : Number of respondents answering low important.

$X_{5}$ : Number of respondents answering not important.

$N$ : The total number of respondents.

\section{Findings and Discussions}

This chapter comprises the analysis, presentation of the data, and interpretation of the results of this study. It is necessary to analyze the data collected to answer the research questions to complete this study properly and meet the research objectives. The research findings are interpreted according to the aims and objectives of the study that were appropriate for the establishment of abstract and conclusion.

1) Influence rates of project consultants in terms of time, cost, and value in projects

Figure 1 shows that $85 \%$ of the respondents accepted that the presence of project consultants in construction project affect positively the time, cost and value of the project, $5 \%$ of respondents showed that in Rwandan construction projects when the designers and contractors are qualified in construction field there is no need of consultants in reducing the time of completion and cost, and improving value, and $10 \%$ of respondents remained neutral on this issue. Figure 1 below indicates that the influence of project consultants in construction projects leads the project to reduce the construction cost and time of completion of the work to sustain its value.

\section{2) Reason for the need for project consultants in projects}

Reasons for the need for project consultants in the Rwandan construction industry were identified and provided in the questionnaire form, where the respondents provided all accurate data according to their overview on the benefits from hiring the project consultants in construction projects. Table 4 below shows the summary of reasons that lead the construction organization to become interesting to hire project consultants. Construction projects goals according to the respondents agreed that it can be achieved when the part of project consultants has a meaningful responsibility in that working field. As

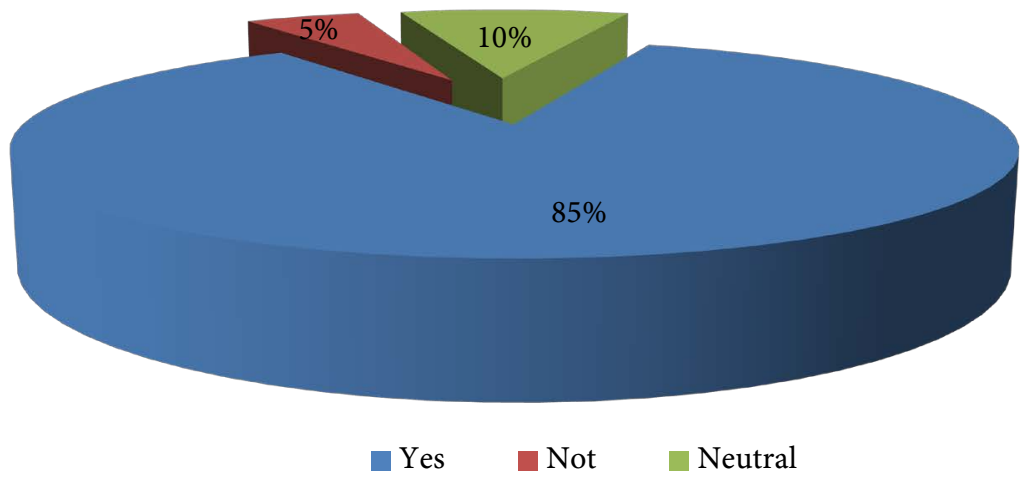

Figure 1. Influence rates of project consultants. 
Table 4. Reason for hiring the project consultants.

\begin{tabular}{|c|c|c|c|c|}
\hline Reasons for having the project consultants & $\mathbf{N}$ & RIA & RII (\%) & Rank \\
\hline To advise on construction project process & 90 & 6650 & 73.8889 & 5 \\
\hline $\begin{array}{l}\text { To improve the quality of the project products in the } \\
\text { present and future }\end{array}$ & 90 & 7575 & 84.1667 & 3 \\
\hline To enhance professionalism & 90 & 4075 & 45.2778 & 10 \\
\hline $\begin{array}{l}\text { To identify project problems and arise real answers } \\
\text { solutions to them }\end{array}$ & 90 & 5325 & 59.1667 & 7 \\
\hline $\begin{array}{l}\text { To reduce and saving the overall project's life cycle cost } \\
\text { according to the client's wishes }\end{array}$ & 90 & 7825 & 86.9444 & 1 \\
\hline To set project goals by giving different instructions & 90 & 5875 & 65.2778 & 6 \\
\hline $\begin{array}{l}\text { To remove major variations that affect construction } \\
\text { project with its attendant cost overrun }\end{array}$ & 90 & 7125 & 79.1667 & 4 \\
\hline To enhance sustainable construction projects & 90 & 4425 & 49.1667 & 9 \\
\hline To keep the time of the construction project & 90 & 7700 & 85.5556 & 2 \\
\hline $\begin{array}{l}\text { To enhance reliability, availability, and client during the } \\
\text { project starting process until the project completion }\end{array}$ & 90 & 4825 & 53.6111 & 8 \\
\hline
\end{tabular}

many researchers stated, while your project faces critical problems that need to be quickly solved in clear ways, the project consultants may be your fast and correct answer. Apart from the different information from the respondents, the main top 5 reasons pushing the clients for hiring the project consultants in their project in the Rwandan construction industry are as follow: to reduce and saving the overall project's life cycle cost according to client's wishes (RII $=86.94 \%)$, to keep the time of construction project (RII $=85.56 \%)$, to improve quality of the project products in the present and future $(\mathrm{RII}=84.17)$, to remove major variations that affect construction project with its attendant cost overrun (RII = 79.17), and to advice on construction project process (RII $=73.89$ ).

\section{3) Factors affecting the performance of project consultants in projects}

The project firm assigns a project consultants' team who is governed under contract conditions, and they perform the services for the client's wishes to meet the project targets from the starting up to the completion of the project. They have themselves to maximize the project revenues, thereby meeting the expectations of the general management of the project and to meet the demands of the client organization, thereby cutting into the project's financial return for their own company. Therefore, several factors may affect the performance of the project consultants' team in Rwandan construction projects as shown in Table 5 below. According to respondents, the main top 10 factors includes the ability to work as a team $(\mathrm{RII}=84.17 \%)$, creativity in controlling own cost and developing own efficiencies (RII $=79.17 \%$ ), timely submission of reports, payment certification and claims $(\mathrm{RII}=77.30 \%)$, ability to make decisions when necessary $(\mathrm{RII}=$ $73.89 \%$ ), coordination of contractors' work promptly ( $\mathrm{RII}=66.94 \%)$, political influence from higher authority (RII $=65.28 \%$ ), accurate and reliable budget 
Table 5. Factors affecting the performance of project consultants.

\section{Factors affecting the performance of}

Adequate technical background

Poor relationship among team members

Ability to coordinate

Ability to make decisions when necessary

Competence of the team

Ability to delegate authority

Ability to work as a team

\section{2) Related to Cost Management}

Accurate and reliable budget estimate

Ability to foresee and budget for potential inflation

Excessive variation orders

Proper planning and scheduling of works

Creativity in controlling their own cost and developing their efficiencies

\section{3) Related to Quality of Work}

Design team experience

Delay in producing design document

Adequate material test records

Excessive variation orders

Excessive errors or omission

\section{4) Time Related}

Coordination of contractors' work promptly

Timely decision making

Timely submission of reports, payment certification, and claims

Time for completing major specified work sections

\section{5) Environmental Related}

Political influence from higher authority

Economic influence in terms of remuneration and allowances

Social in terms of family relations

Weather influence

Level of technological advancement

\section{6) Others}

\section{Project type}

Project value

Project duration

Urgency
RII (\%) Rank

N RIA

90

90

90

90

90

90

5

$\begin{array}{lll}4975 & 55.28 & 17 \\ 2550 & 28.33 & 29 \\ 5100 & 56.67 & 16 \\ 2875 & 31.94 & 27 \\ 3325 & 36.90 & 26\end{array}$

$\begin{array}{lll}6025 & 66.94 & 5\end{array}$


estimate $(\mathrm{RII}=64.17 \%)$, timely decision making $(\mathrm{RII}=63.61 \%)$, proper planning and scheduling of works (RII $=62.50 \%)$, and economic influence in terms of remuneration and allowances ( $\mathrm{RII}=61.94 \%)$.

\section{4) Reason behind non-application of project consulting in projects}

The project consulting method is one of the best and most reliable methods, especially in the construction industry, as this method has been shown to increase productivity at a lower cost. The construction industry in Rwanda is progressing significantly as compared to the surrounding countries, but the use of the project consultancy method is sometimes unsuccessful due to a variety of reasons as shown in Table 6 below. According to the respondents, the five highly ranked reasons are lack of knowledge and practice in project consulting (RII = $82.22 \%$ ), lack of well-trained project consulting professionals (RII $=78.06 \%$ ), lack of training opportunities in project consulting (RII $=76.11 \%$ ), lack of knowledge and experience in addition to the senior management opposition (RII $=70.28 \%$ ), and lack of local project consulting guidelines and information (RII = $68.05 \%)$.

Table 6. Reasons that hinder the implementation of project consulting.

\begin{tabular}{|c|c|c|c|c|}
\hline Reasons that hinder the implementation of project consulting & $\mathbf{N}$ & RIA & RII (\%) & Rank \\
\hline $\begin{array}{l}\text { Lack of knowledge and experience in addition to the senior } \\
\text { management opposition }\end{array}$ & 90 & 6325 & 70.28 & 4 \\
\hline Lack of training opportunities in project consulting & 90 & 6850 & 76.11 & 3 \\
\hline Lack of well-trained project consulting professionals & 90 & 7025 & 78.06 & 2 \\
\hline Not suitable for low-cost project & 90 & 3975 & 44.17 & 9 \\
\hline $\begin{array}{l}\text { The higher management does not believe in the benefits of project } \\
\text { consulting }\end{array}$ & 90 & 5725 & 63.61 & 6 \\
\hline Too expensive to carry out project consulting & 90 & 3700 & 41.11 & 10 \\
\hline Interruption to normal work schedule & 90 & 4800 & 53.33 & 7 \\
\hline Lack of knowledge and practice in project consulting & 90 & 7400 & 82.22 & 1 \\
\hline Lack of local project consulting guidelines and information & 90 & 6125 & 68.05 & 5 \\
\hline Other factors, like the nature of works and the owner of the project & 90 & 4450 & 49.44 & 8 \\
\hline
\end{tabular}

\section{Conclusions}

The research in this article paper was to investigate the relationship between project consultants' performance and project success of the Rwandan construction industry as it is more significant in the construction industry to have a better understanding of the project consultants' performance and their resultant impacts on project success.

It is more important that the project consultants must have a detailed understanding of several constraints like project budgets, project time given for completion, and all resources necessitated for the project due to their skills, knowledge, and experience to manage projects correctly and clearly. In addition, 
project consulting is only useful when participating in the project from starting to the completion of the project. From the results of the study, it is obvious that in the Rwandan construction industry, there is a close and strong relationship between the performance of the project consultants and the success of the project. The survey results show that even if there are many obstacles in the use of project consultants in the Rwandan construction industry such as lack of knowledge and practice in project consulting, lack of well-trained project consulting professionals, lack of training opportunities in project consulting, lack of knowledge and experience in addition to the senior management opposition, and lack of local project consulting guidelines and information; they are needed in the construction project to make it more successful through reducing and saving the overall project's life cycle cost according to client's wishes, keeping time of construction project, improving quality of the project products in the present and future, removing major variations that affect construction project with its attendant cost overrun, and advising on construction project process. The project consultant's leading skills and knowledge automatically guide the project to complete with accurate time, budget, and quality to make the project successful. Therefore, it is more important to remark that the good performance of the project consultants in any industry, especially in the construction industry is conducive to the smooth implementation of the project and the smooth progress of various activities at all stages of the project. Finally, we can conclude that if we want to successfully start and complete any construction project, then we must have a project consultant.

\section{Acknowledgements}

The sincere acknowledgements to fellow all interview ninety respondents for the time sacrificed to respond to the assessment questionnaires.

\section{Conflicts of Interest}

All authors declare no conflicts of interest regarding the publication of this paper.

\section{References}

[1] Nikumbh, A.R. and Pimplikar, S.S. (2014) Role, Services of Project Management Consultancy in Construction Projects \& the Audit Process. Journal of Mechanical and Civil Engineering (IOSR-JMCE), 11, 22-31.

https://doi.org/10.9790/1684-11342231

[2] Nikumbh, A.R. and Pimplikar, S.S. (2014) Role of Project Management Consultancy in Construction Project. Journal of Mechanical and Civil Engineering (IOSR-JMCE), 10, 14-19. https://doi.org/10.9790/1684-1061419

[3] Ramlee, N., Tammy, N.J., Raja Mohd Noor, R.N.H., Ainun Musir, A., Abdul Karim, N., Chan, H.B. and Mohd Nasir, S.R. (2016) Critical Success Factors for Construction Project. AIP Conference Proceedings, 1774, Article ID: 030011. https://doi.org/10.1063/1.4965067 
[4] Wite, A. (1988) Measurement of Project Success. International Journal of Project Management, 6, 164-170. https://doi.org/10.1016/0263-7863(88)90043-9

[5] Ashley, D., Jaselskis, E. and Lurie, C.B. (1987) The Determinants of Construction Project Success. Project Management Journal, 18, 69-79.

[6] Wang, X. and Huang, J. (2006) The Relationships between Key Stakeholders' Project Performance and Project Success: Perceptions of Chinese Construction Supervising Engineers. International Journal of Project Management, 24, 253-260.

[7] Chan, A.P.C., Scott, D. and Lam, E.W.M. (2002) Framework of Success Criteria for Design/Build Projects. ASCE Journal of Management in Engineering, 18, 120-128.

[8] Lam, E., Chan, A. and Chan, D. (2008) Determinants of Successful Design-Build Projects. Journal of Construction Engineering and Management, 134, 333-341. https://doi.org/10.1061/(ASCE)0733-9364(2008)134:5(333)

[9] Collins, A. and Baccarini, D. (2004) Project Success-A Survey. Journal of Construction Research, 5, 211-231. https://doi.org/10.1142/S1609945104000152

[10] Chan, A.P.C. and Chan, A.P.L. (2004) Key Performance Indicators for Measuring Construction Success. Benchmarking: An International Journal, 11, 203-221. https://doi.org/10.1108/14635770410532624

[11] Pheng, L. and Chuan, Q. (2006) Environmental Factors and Work Performance of Project Managers in the Construction Industry. International Journal of Project Management, 24, 24-37. https://doi.org/10.1016/j.ijproman.2005.06.001

[12] Gomes, J. and Romão, M. (2016) Improving Project Success: A Case Study Using Benefits and Project Management. Procedia Computer Science, 100, 489-497. https://doi.org/10.1016/j.procs.2016.09.187

[13] Nelson, R.R. (2005) Project Retrospectives: Evaluating Project Success, Failure, and Everything in between. MIS Quarterly Executive, 4, 361-371.

[14] Turner, J.R. (2004) Five Necessary Conditions for Project Success. International Journal of Project Management, 22, 349-350.

https://doi.org/10.1016/j.ijproman.2004.02.001

[15] Baccarini, D. (1999) The Logical Framework Method for Defining Project Success. Project Management Journal, 30, 25-32. https://doi.org/10.1177/875697289903000405

[16] Rockart, J.F. (1982) The Changing Role of the Information Systems Executive: A Critical Success Factors Perspective. Sloan Management Review, 24, 3-13.

[17] Belassi, W. and Tukel, O.I. (1996) A New Framework for Determining Critical Success/Failure Factors in Projects. International Journal of Project Management, 14, 141-151. https://doi.org/10.1016/0263-7863(95)00064-X

[18] Alzahrani, J.I. and Emsley, M.W. (2013) The Impact of Contractors' Attributes on Construction Project Success: A Post Construction Evaluation. International Journal of Project Management, 31, 313-322. https://doi.org/10.1016/j.ijproman.2012.06.006

[19] Pinto, J.K. and Slevin, D.P. (1987) Critical Factors in Successful Project Implementation. IEEE Transactions on Engineering Management, 34, 22-27. https://doi.org/10.1109/TEM.1987.6498856

[20] Cheung, S.-O., Suen, H.C.H. and Cheung, K.K.W. (2004) PPMS: A Web-Based Construction Project Performance Monitoring System. Automation in Construction, 13, 361-376. https://doi.org/10.1016/j.autcon.2003.12.001

[21] Ismail, D. (2005) Services Provided by Project Management Consultant in Malay- 
sian Construction Industry. MSc Thesis, Faculty of Civil Engineering, Universiti Teknologi Malaysia, Skudai.

[22] Liphadzi, M., Aigbavboa, C. and Thwala, W. (2015) Relationship between Leadership Styles and Project Success in the South Africa Construction Industry. Procedia Engineering, 123, 284-290. https://doi.org/10.1016/j.proeng.2015.10.091

[23] Rona, D.C. (1984) How to Strengthen Client-Consultant Relationships. Civil Engineering, 54, 52-54.

[24] Zulkiffli, N.A., Latiffi, A.A., Mohd Ahnuar, E., Mohd Nordin, R., Yunus, J. and Abdul Rahman, N.A. (2019) Review on Project Manager's Leadership Skills in the Pre-Construction Phase of Sustainable Construction Projects. MATEC Web of Conferences, 266, Article No. 01011. https://doi.org/10.1051/matecconf/201926601011

[25] Wen, Q., Qiang, M. and An, N. (2017) Collaborating with Construction Management Consultants in Project Execution: Responsibility Delegation and Capability Integration. Journal of Construction Engineering and Management, 143, Article ID: 04017021. https://doi.org/10.1061/(ASCE)CO.1943-7862.0001312

[26] Robichaud, L.B. and Anantatmula, V.S. (2011) Greening Project Management Practices for Sustainable Construction. Journal of Management in Engineering, 27, 48-57. https://doi.org/10.1061/(ASCE)ME.1943-5479.0000030

[27] Del Río, M., Izquierdo, P. and Salto-Weis, I. (2010) Sustainable Construction: Construction and Demolition Waste Reconsidered. Waste Management \& Research, 28, 118-129. https://doi.org/10.1177/0734242X09103841

[28] Jaworski, M. and Samanta, I. (2006) Understanding the Role of Project Manager. Journal of Commerce, 3, 1-9.

[29] Hills, M., Fox, C., Fonf, P. and Skitmore, M. (2008) The Role of Project Managers in Construction Industry Development. Proceedings AACE International s 52nd Annual Meeting \& ICEC s 6 th World Congress on Cost Engineering, Project Management and Quantity Surveying, Toronto, DEV.14.1-DEV.14.9.

[30] Fernandez-Montes, S. (2017) Impact of Construction Project Management on DGNB Sustainability Certification. Master Thesis, Aalborg University, Denmark.

[31] Wu, P. and Low, S.P. (2010) Project Management and Green Buildings: Lesson from the Rating Systems. Journal of Professional Issues in Engineering Education and Practice, 136, 64-70. https://doi.org/10.1061/(ASCE)EI.1943-5541.0000006

[32] Delnavaz, M. (2012) Project Managers. Role in Sustainable Building Process. Master's Thesis, Chalmers University of Technology, Goteborg.

[33] Hwang, B.G. and Tan, J.S. (2012) Green Building Project Management: Obstacles and Solutions for Sustainable Development. Sustainable Development, 20, 335-349. https://doi.org/10.1002/sd.492

[34] Hăkkinen, T. and Belloni, K. (2011) Barriers and Drivers for Sustainable Building. Building Research \& Information, 39, 239-255. https://doi.org/10.1080/09613218.2011.561948

[35] Wu, Z., Shen, L., Yu, A.T.W. and Zhang, X. (2016) A Comparative Analysis of Waste Management Requirements between Five Green Building Rating Systems for New Residential Buildings. Hournal of Cleaner Production, 112, 895-902. https://doi.org/10.1016/j.jclepro.2015.05.073

[36] Almansour, Y. (2012) The Relationship between Leadership Styles and Motivation of Managers Conceptual Framework. Journal of Arts, Science \& Commerce, 3 , 161-166. 
[37] Pryke, S. and Smyth, H. (2006) The Management of Complex Projects: A Relationship Approach. Blackwell, Oxford.

[38] PMI (2013) A Guide to the Project Management Body of Knowledge (PMBOK Guide). Project Management Institute, Newtown Square.

[39] Zuo, J., Zhao, X.B., Nguyen, Q.B.M., Ma, T., Gao, S., Anumba, C. and Thomson, D. (2018) Soft Skills of Construction Project Management Professionals and Project Success Factors: A Structural Equation Model. Engineering, Construction and Architectural Management, 25, 425-442. https://doi.org/10.1108/ECAM-01-2016-0016

[40] Novo, B., Landis, E.A. and Haley, M.L. (2017) Leadership and Its Role in the Success of Project Management. Journal of Leadership, Accountability and Ethics, 14, 73-78.

[41] Serhan, N. (2016) Project Manager's Communication Skills and Stakeholder Engagement in Sustainable Construction Projects. Master Thesis, Malmo University, Malmö.

[42] Schmid, B. and Adams, J. (2008) Motivation in Project Management: The Project Manager's Perspective. Project Management Journal, 39, 60-71.

https://doi.org/10.1002/pmj.20042

[43] Zulch, B.G. (2014) Communication Skills Impact on Sustainable and Green Project Management. Proceedings of the World Sustainable Building (SB14) Conference, Vol. 5, 676-682.

[44] Giotis, T.C. (2010) Leadership through Conflict: Grow and Advance Project Teams! PMP Global Congress 2010-EMEA, Milan, 12 May 2010, 1-10.

[45] Bruce, S. (2014) Handbook.

[46] Farooqui, R.U. (2008) An Exploratory Study Probing into the Factors Causing Safety Nonperformance in the Pakistani Construction Industry. 45th IEP Convention, Karachi, 1-12.

[47] Glavinich, T.E. (2008) Contractor's Guide to Green Building Construction. John Wiley \& Sons, Hoboken. https://doi.org/10.1002/9780470259979

[48] Foley, J. and Macmillan, S. (2005) Patterns of Interactions in Construction Team Meetings. Co Design, 1, 21-37. https://doi.org/10.1080/15710880412331289926

[49] APM (Association for Project Management) (2018). https://www.apm.org.uk/bodyofknowledge/people/interpersonal-skills/negotiation 